\title{
Comparative Study of Concrete Filled Steel Tube Columns under Axial Compression
}

\author{
Pandu Ranga Kirankumar.T \\ Student of final year M.Tech Structural Engineering \\ Mandava Institute of Engineering \& Technology \\ Andhra Pradesh
}

\author{
S.V.V.K.Babu, M.Tech \\ D.Aditya Sai Ram, M.Tech \\ Assistant Professor, Civil Engg. Department \\ Assistant Professor, Civil Engg. Department \\ Sri Vasavi Institute of Engineering \& Technology \\ Andhra Pradesh \\ Mandava Institute of Engineering \& Technology \\ Andhra Pradesh
}

\begin{abstract}
In recent days, due to the expansion of cities it is required to construct the high storey buildings. Composite buildings prove to be promising for multi storey building. As a result, composite columns have recently undergone increased usage throughout the world, which has been influenced by the improvement of high strength concrete enabling these columns to be considerably economized. Columns are designed to resist the majority of axial force by concrete alone can be further economized by the use of thin walled steel tube. The paper discusses about the behavior of the composite column and various codal provisions. Experimental research carried out by comparative study between experimental results and analytical results for hollow steel tube (HST) and concrete filled steel tubes (CFST) under axial compression. To compare the experimental results of CFST with AISC-LRFD 2005 and Eurocode-4. The investigation is carried out on HST \& CFST specimens of Rectangular cross section with three different sizes. The grade of concrete used for infill concrete is M20 and M40. The tests on said CFST specimens are carried out with the help of compression testing machine. The axial load is applied gradually on specimens. This paper presents the details of study carried out and the conclusions arrived.
\end{abstract}

Keywords: HST, CFST, AISC-LRFD, in filled concrete, buckling etc.,

\section{INTRODUCTION}

Concrete filled steel tubular (CFST) members utilize the advantages of both steel and concrete. They comprise of a steel hollow section of circular or rectangular shape filled with plain or reinforced concrete. They are widely used in high-rise and multistory buildings as columns and beam-columns, and as beams in low-rise industrial buildings where a robust and efficient structural system is required.

There are a number of distinct advantages related to such structural systems in both terms of structural performance and construction sequence. The inherent buckling problem related to thin-walled steel tubes is either prevented or delayed due to the presence of the concrete core. Furthermore, the performance of the concrete in-fill is improved due to confinement effect exerted by the steel shell. The distribution of materials in the cross section also makes the system very efficient in term of its structural performance. The steel lies at the outer perimeter where it performs most effectively in tension and bending. It also provides the greatest stiffness as the material lies furthest from the centroid. This, combined with the steel's much greater modulus of elasticity, provides the greatest contribution to the moment of inertia. The concrete core gives the greater contribution to resisting axial compression.

The hollow tubes alone were designed in such a way that they are capable of supporting the floor load up to three or four storey height. Once the upper floors were completed, the concrete was pumped into the tubes from the bottom. To facilitate easy pumping the tubes were continuous at the floor level. Modern pumping facility and high performance concrete make pumping three or four storey readily achievable. Due to the simplicity of the construction sequence, the project can be completed in great pace. 


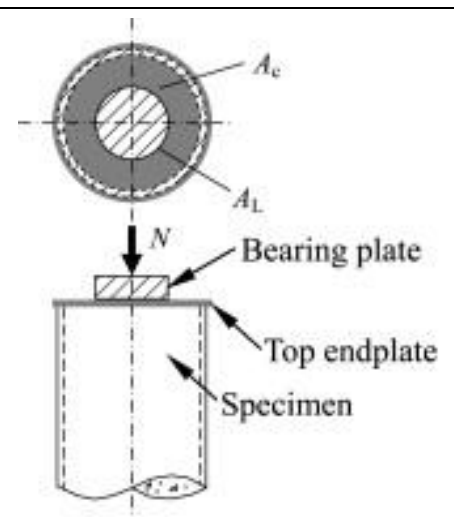

(a)

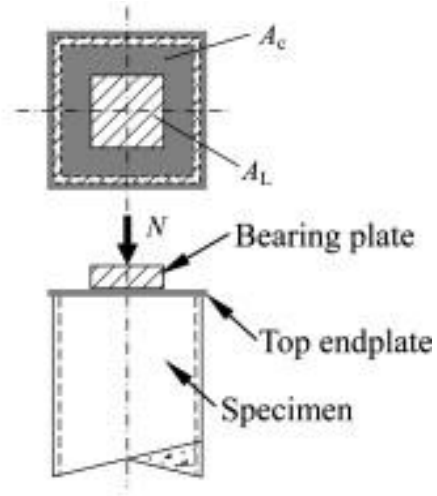

(b)

Fig. Shows plan and section of CFST columns

\section{EXPERIMENTAL WORK}

For experimental investigation axial load is applied on HST \& CFST specimen. While testing care taken that the end surfaces on which concrete filled steel tubes keeping for testing should be the plane. All specimens were tested in Compression Testing Machine and are simply supported at both ends.

\section{Details of column specimens:}

$>$ All the steel tubes have same c/s as $145 \mathrm{~mm}$ X 82mm X 4.8mm.

$>$ A total of 18 columns were tested (6 HST and 12 CFST).

$>2$ HST and 2 CFST columns of height $0.5 \mathrm{~m}$ were tested for axial compression loading.

$>2$ HST and 2 CFST columns of height $1 \mathrm{~m}$ were tested for axial compression loading.

$>2$ HST and 2 CFST columns of height $1.5 \mathrm{~m}$ were tested for axial compression loading.

\section{Materials used are:}

1. Hollow steel tubular section

2. Nitowrap 410 (epoxy)

3. Cement

4. Fine aggregate

5. Coarse aggregate

6. Steel bars

7. Water

8. Curing compound

Table1. Details of column specimens

\begin{tabular}{|c|c|c|c|c|c|c|c|}
\hline \multirow{2}{*}{$\begin{array}{c}\text { Sl. } \\
\text { No. }\end{array}$} & \multirow{2}{*}{$\begin{array}{c}\text { Specimen } \\
\text { designation }\end{array}$} & \multicolumn{3}{|c|}{$\begin{array}{c}\text { Dimensions } \\
\text { (mm) }\end{array}$} & \multirow{2}{*}{$\begin{array}{c}\text { Length } \\
\text { (mm) }\end{array}$} & L/D & $\begin{array}{c}\text { Concrete } \\
\text { Grade }\end{array}$ \\
\cline { 3 - 5 } & $(\mathbf{B})$ & $\mathbf{( D )}$ & $\mathbf{( t )}$ & & & \\
\hline 1 & HSTC-01 & 82 & 145 & 4.8 & 500 & 3.45 & $\ldots \ldots$ \\
\hline 2 & HSTC-02 & 82 & 145 & 4.8 & 500 & 3.45 & $\ldots \ldots$ \\
\hline 3 & HSTC-03 & 82 & 145 & 4.8 & 1000 & 6.90 & $\ldots \ldots$ \\
\hline 4 & HSTC-04 & 82 & 145 & 4.8 & 1000 & 6.90 & $\ldots \ldots$ \\
\hline 5 & HSTC-05 & 82 & 145 & 4.8 & 1500 & 10.34 & $\ldots \ldots$ \\
\hline 6 & HSTC-06 & 82 & 145 & 4.8 & 1500 & 10.34 & $\ldots$. \\
\hline 7 & CFSTC-01 & 82 & 145 & 4.8 & 500 & 3.45 & $\mathrm{M}_{20}$ \\
\hline 8 & CFSTC-02 & 82 & 145 & 4.8 & 500 & 3.45 & $\mathrm{M}_{20}$ \\
\hline 9 & CFSTC-03 & 82 & 145 & 4.8 & 500 & 3.45 & $\mathrm{M}_{40}$ \\
\hline 10 & CFSTC-04 & 82 & 145 & 4.8 & 500 & 3.45 & $\mathrm{M}_{40}$ \\
\hline 11 & CFSTC-05 & 82 & 145 & 4.8 & 1000 & 6.90 & $\mathrm{M}_{20}$ \\
\hline 12 & CFSTC-06 & 82 & 145 & 4.8 & 1000 & 6.90 & $\mathrm{M}_{20}$ \\
\hline 13 & CFSTC-07 & 82 & 145 & 4.8 & 1000 & 6.90 & $\mathrm{M}_{40}$ \\
\hline 14 & CFSTC-08 & 82 & 145 & 4.8 & 1000 & 6.90 & $\mathrm{M}_{40}$ \\
\hline 15 & CFSTC-09 & 82 & 145 & 4.8 & 1500 & 10.34 & $\mathrm{M}_{20}$ \\
\hline 16 & CFSTC-10 & 82 & 145 & 4.8 & 1500 & 10.34 & $\mathrm{M}_{20}$ \\
\hline 17 & CFSTC-11 & 82 & 145 & 4.8 & 1500 & 10.34 & $\mathrm{M}_{40}$ \\
\hline 18 & CFSTC-12 & 82 & 145 & 4.8 & 1500 & 10.34 & $\mathrm{M}_{40}$ \\
\hline
\end{tabular}




\section{Properties of the basic materials:}

1. Hollow steel tubes: It confirms to IS-4923:1997

Table2. Dimensions and geometrical properties of RHS

\begin{tabular}{|l|c|c|c|c|}
\hline \multirow{2}{*}{$\begin{array}{l}\text { Grade of } \\
\text { Steel }\end{array}$} & Minimum & Yield & Minimum & \multicolumn{2}{|c|}{$\begin{array}{c}\text { Percentage Elongation, Min for } \\
\text { sizes (\%) }\end{array}$} \\
\cline { 4 - 5 } & Stress & Stress \\
(MPa) & (MPa) & $\begin{array}{c}\text { Less than or } \\
\text { equal to } \\
25.4 m m\end{array}$ & $\begin{array}{c}\text { Greater than } \\
\mathbf{2 5 . 4 m m}\end{array}$ \\
\hline Yst 310 & 310 & 450 & 8 & 10 \\
\hline
\end{tabular}

Table3. Mechanical Properties of Cold Formed Steel Section

\begin{tabular}{|c|c|c|c|c|c|c|c|c|c|}
\hline RHS & Thickness & $\begin{array}{c}\text { Sectional } \\
\text { Area }\end{array}$ & Weight & \multicolumn{2}{|c|}{$\begin{array}{c}\text { Moment of } \\
\text { Inertia }\end{array}$} & \multicolumn{2}{|c|}{$\begin{array}{c}\text { Radius of } \\
\text { Gyration }\end{array}$} & \multicolumn{2}{|c|}{$\begin{array}{c}\text { Elastic } \\
\text { Modulus }\end{array}$} \\
\hline$(\mathrm{D} \times \mathrm{x})$ & $(\mathrm{t})$ & $(\mathrm{A})$ & $(\mathrm{W})$ & $\left(\mathrm{I}_{\mathrm{xx}}\right)$ & $\left(\mathrm{I}_{\mathrm{yy}}\right)$ & $\left(\mathrm{r}_{\mathrm{xx}}\right)$ & $\left(\mathrm{r}_{\mathrm{yy}}\right)$ & $\left(\mathrm{Z}_{\mathrm{xx}}\right)$ & $\left(\mathrm{Z}_{\mathrm{yy}}\right)$ \\
\hline $\mathrm{mm}$ & $\mathrm{mm}$ & $\mathrm{cm}^{2}$ & $\mathrm{~kg} / \mathrm{m}$ & $\mathrm{cm}^{4}$ & $\mathrm{~cm}^{4}$ & $\mathrm{~cm}$ & $\mathrm{~cm}$ & $\mathrm{~cm}^{3}$ & $\mathrm{~cm}^{3}$ \\
\hline $145 \times 82$ & 4.8 & 20.28 & 15.92 & 555.16 & 228.5 & 5.23 & 3.36 & 55.73 & 94.93 \\
\hline
\end{tabular}

2. Cement: OPC 53 grade cement confirming to IS $12269: 1987$ is used in the current investigation.

Table4. Properties of Cement

\begin{tabular}{|c|c|c|c|c|}
\hline $\begin{array}{l}\text { Serial } \\
\text { No }\end{array}$ & \multicolumn{2}{|c|}{ Characteristics } & Results & $\begin{array}{l}\text { Requirements as } \\
\text { per IS } 12269 \text { - } 1987\end{array}$ \\
\hline 1 & \multicolumn{2}{|c|}{ Fineness } & $340 \mathrm{~m}^{2} / \mathrm{kg}$ & $\begin{array}{l}\text { Should be more than } \\
225 \mathrm{~m}^{2} / \mathrm{kg}\end{array}$ \\
\hline 2 & \multicolumn{2}{|c|}{ Soundness } & $4 \mathrm{~mm}$ & $\begin{array}{l}\text { Should be less than } \\
\text { or equal to } 10 \mathrm{~mm}\end{array}$ \\
\hline \multirow[b]{2}{*}{3} & \multirow[b]{2}{*}{$\begin{array}{l}\text { Setting } \\
\text { Time }\end{array}$} & Initial & 125 minutes & $\begin{array}{c}\text { Should be more than } \\
30 \text { minutes }\end{array}$ \\
\hline & & Final & 220 minutes & $\begin{array}{l}\text { Should be less than } \\
\text { or equal to } \\
600 \text { minutes }\end{array}$ \\
\hline 4 & \multicolumn{2}{|c|}{ Specific Gravity } & 3.13 & $\ldots \ldots \ldots \ldots$ \\
\hline 5 & \multicolumn{2}{|c|}{$\begin{array}{c}\text { Standard } \\
\text { Consistency }\end{array}$} & $32.40 \%$ & $\cdots$ \\
\hline
\end{tabular}

3. Fine aggregate: Manufactured sand confirming to IS-383:1970 belonging to zone II is used in the current investigation.

Table5. Properties of Manufactured sand

\begin{tabular}{|c|c|c|}
\hline 1 & Bulk Density $\left(\mathrm{kg} / \mathrm{m}^{3}\right)$ & 1540 \\
\hline 2 & Specific Gravity & 2.59 \\
\hline 3 & Fineness Modulus & 2.97 \\
\hline 4 & Water Absorption & $4.5 \%$ \\
\hline
\end{tabular}

4. Coarse aggregate: Crushed stone aggregates confirming to IS 383:1970 were used as coarse aggregates. The maximum size of crushed stone dust was $12.5 \mathrm{~mm}$. The specific gravity of crushed stone aggregate used was found to be 2.63 and the water absorption was found to be $0.72 \%$.

5. Chemical admixture: The chemical admixture basically used in the concrete for current experimental investigation is a high performance super plasticizer which is derived from carboxylic ether. 
Pandu Ranga Kirankumar.T et al.

Table6. Characteristics of Master Glenium Sky 8630

\begin{tabular}{|c|c|c|}
\hline SI.No. & Properties & Values \\
\hline 1 & Specific Gravity & 1.08 \\
\hline 2 & Chloride ion content & 0.0075 \\
\hline 3 & Relative Density & 1.075 at $25^{\circ} \mathrm{C}$ \\
\hline 4 & $\mathrm{P}^{\mathrm{H}}$ & 6.77 \\
\hline
\end{tabular}

Concrete: The concrete used in the current experimental investigation was produced in the Ready Mix Concrete (RMC) plant. Two grades of concrete $\mathrm{M}_{20}$ and $\mathrm{M}_{40}$ were used. Both the concrete had collapsible slump so that concrete can easily flow into the steel tube by its own.

6. Curing compound: The curing compound used in the current experimental investigation was basically based the membrane curing theory. The curing compound used is Master Kure 181 which is a non degrading, membrane forming liquid basically derived from the acrylic resin.

Table7. Characteristics of Master Kure 181

\begin{tabular}{|c|c|c|}
\hline SI.No. & Properties & Values \\
\hline 1 & Specific Gravity & 0.82 at $25^{\circ} \mathrm{C}$ \\
\hline 2 & Flash Point & $30^{\circ} \mathrm{C}$ \\
\hline 3 & Drying Time & 45 minutes at $25^{\circ} \mathrm{C}$ \\
\hline
\end{tabular}

Fig. CFST columns before and after application of curing compound

\section{Experimental Test Setup:}

The concrete filled steel tube specimens of different cross sections are tested for their load carrying capacity under axial compression on the compression testing machine. The actual test setup is as shown in following figure. The specimen of CFST is placed centrally on plates of compression testing machine and load is applied gradually. The capacity of compression testing machine in our college is 200 tonne. The readings werw taken on dial guage and tabulated.

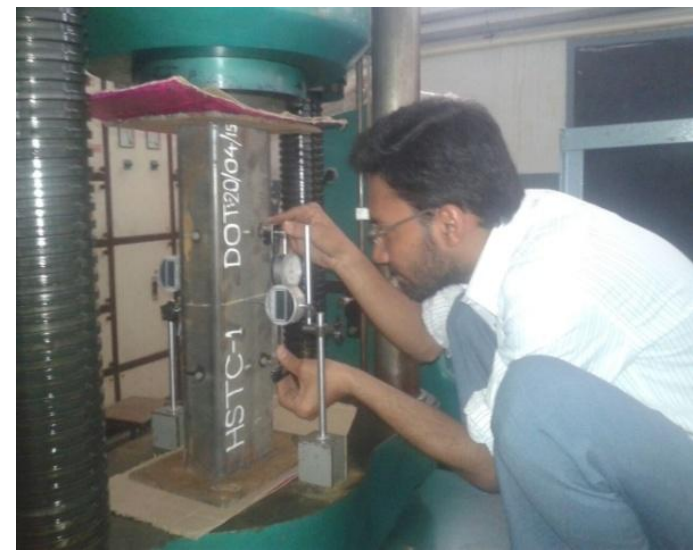

Fig. Test set up of CFST Column for axial loading 
Table8. Test results of HSTC-03 to HSTC-06

\begin{tabular}{|c|c|c|c|}
\hline Sl. No & Specimen Designation & Height of Column (m) & $\begin{array}{c}\text { Ultimate Axial } \\
\text { Compressive Load (kN) }\end{array}$ \\
\hline 1 & HSTC-03 & 1.0 & 688.66 \\
\hline 2 & HSTC-04 & 1.0 & 680.81 \\
\hline 3 & HSTC-05 & 1.5 & 608.22 \\
\hline 4 & HSTC-06 & 1.5 & 622.94 \\
\hline
\end{tabular}

Hollow Steel Tubular Column (HSTC-05 to HSTC-12)

Table9. Test results of HSTC-05 to HSTC-12

\begin{tabular}{|c|c|c|c|c|}
\hline Sl. No & Specimen Designation & $\begin{array}{c}\text { Height of } \\
\text { Column }(\mathbf{m})\end{array}$ & $\begin{array}{c}\text { Grade of } \\
\text { concrete infilled }\end{array}$ & $\begin{array}{c}\text { Ultimate Axial } \\
\text { Compressive Load (kN) }\end{array}$ \\
\hline 1 & HSTC-05 & 1.0 & $\mathrm{M}_{20}$ & 797.55 \\
\hline 2 & HSTC-06 & 1.0 & $\mathrm{M}_{20}$ & 808.34 \\
\hline 3 & HSTC-07 & 1.0 & $\mathrm{M}_{20}$ & 819.14 \\
\hline 4 & HSTC-08 & 1.0 & $\mathrm{M}_{20}$ & 830.91 \\
\hline 5 & HSTC-09 & 1.5 & $\mathrm{M}_{40}$ & 725.94 \\
\hline 6 & HSTC-10 & 1.5 & $\mathrm{M}_{40}$ & 741.64 \\
\hline 7 & HSTC-11 & 1.5 & $\mathrm{M}_{40}$ & 755.37 \\
\hline 8 & HSTC-12 & 1.5 & $\mathrm{M}_{40}$ & 769.10 \\
\hline
\end{tabular}

\section{COMPARISON OF TeSt Results With CODES}

\section{EUROCODE 4:}

In this research, similar to for end -loaded braced members, the axial force Nsd and the maximum end moment Msd are determined from a first order structural analysis. For each of the bending axis of the column it has to be verified that

$$
N_{S d} \leq \chi_{k} N_{0}
$$

Where $\chi_{k}$ is a reduction factor due to buckling. The buckling curves can also be described in the form of an equation:

$$
\chi_{k}=\frac{1}{\phi+\sqrt{\phi^{2}-\bar{\lambda}^{2}}}
$$

Where,

$$
\phi=0.5\left[1+\alpha(\bar{\lambda}-0.2)+\bar{\lambda}^{2}\right]
$$

Where $\alpha$ depends on the buckling effects, a value of 0.21 was adopted for CFST column. The relative slenderness of $\lambda$ is given by:

$$
\bar{\lambda}=\sqrt{\frac{N_{0}}{N_{c r}}}
$$

In which $\mathrm{N}_{\mathrm{cr}}$ is the critical buckling stress resultant given by:

$$
N_{c r}=\frac{\pi^{2}(E I)_{e}}{L_{e}^{2}}
$$

Where Le is the effective length and $(\mathrm{EI})_{\mathrm{e}}$ is the actual elastic stiffness.

$$
(E I)_{e}=E_{s} I_{s}+0.8 \frac{E_{c}}{1.35} I_{c}
$$


Pandu Ranga Kirankumar.T et al.

In this research it is proposed:

$$
(E I)_{e}=E_{s} I_{s}+0.8 \beta_{c} E_{c} I_{c}
$$

Where $\beta_{\mathrm{c}}$ is the load effect;

$I_{c}, I_{s}$ are the concrete, steel moments of inertia;

$\mathrm{E}_{\mathrm{s}}$ is the Young's modulus of steel;

$\mathrm{E}_{\mathrm{c}}$ is the secant modulus for the concrete determined for the appropriate concrete grades, equal to $9500\left(\mathrm{f}_{\mathrm{c}}{ }^{\prime}+8\right)^{1 / 3} \mathrm{In} \mathrm{MPa}$ :

$F_{c}$ is the characteristic compressive cylinder strength of concrete at 28 days.

\section{AISC-LFRD 2005:}

$\mathbf{P}_{\mathbf{n}}=\mathrm{A}_{\mathrm{s}} \mathrm{F}_{\mathrm{cr}}$

$$
\left(0.658^{\lambda}{ }_{c}^{2}\right) F_{m y} \quad\left(\lambda_{c} \leq 1.5\right)
$$

$\mathrm{F}_{\mathrm{cr}}=\{$

$$
\left(0.877 / \lambda_{\mathrm{c}}^{2}\right) \mathrm{F}_{\mathrm{my}}\left(\lambda_{\mathrm{c}}>1.5\right) \mathrm{r}_{\mathrm{m}}
$$

$\mathrm{A}_{\mathrm{c}} \mathrm{A}_{\mathrm{z}}$

$\lambda_{\mathrm{c}}=\frac{K L}{\mathrm{rm} \pi} \sqrt{\frac{\text { Fmy }}{\mathrm{Em}}}$

$\mathrm{F}_{\mathrm{my}}=\mathrm{f}_{\mathrm{y}}+0.85 \mathrm{f}_{\mathrm{c}}{ }^{1}\left(\frac{\mathrm{Ac}}{\mathrm{Az}}\right)$

$\mathrm{E}_{\mathrm{m}}=\mathrm{E}_{\mathrm{z}}+0.4\left(\frac{\mathrm{Ac}}{\mathrm{Az}}\right) \mathrm{E}_{\mathrm{c}}$

\begin{tabular}{|c|c|c|c|c|c|c|}
\hline \multirow{3}{*}{$\begin{array}{c}\text { Serial } \\
\text { No }\end{array}$} & \multirow{3}{*}{$\begin{array}{l}\text { Specimen } \\
\text { Designation }\end{array}$} & \multirow{3}{*}{$\begin{array}{c}\text { Experimental } \\
\text { Ultimate } \\
\text { Load }\left(\mathbf{P}_{\text {EXP }}\right)(\mathbf{k N})\end{array}$} & \multicolumn{4}{|c|}{ Predicted Design Load by } \\
\hline & & & \multicolumn{2}{|c|}{ AISC-LRFD-2005 } & \multicolumn{2}{|c|}{ Eurocode-4 } \\
\hline & & & $\mathbf{P}_{\text {LRFD }}(\mathbf{k N})$ & $\mathbf{P}_{\text {EXP }} / \mathbf{P}_{\text {LRFD }}$ & $\mathbf{P}_{\mathrm{EC} 4}(\mathbf{k N})$ & $\mathbf{P}_{\mathrm{EXP}} / \mathbf{P}_{\mathrm{EC} 4}$ \\
\hline 1 & CFSTC-1 & 884.86 & 752.08 & 1.18 & 787.03 & 1.12 \\
\hline 2 & CFSTC-2 & 912.33 & 752.08 & 1.21 & 787.30 & 1.16 \\
\hline 3 & CFSTC-3 & 1020.24 & 883.33 & 1.15 & 943.21 & 1.08 \\
\hline 4 & CFSTC-4 & 1059.48 & 883.33 & 1.20 & 943.21 & 1.12 \\
\hline 5 & CFSTC-5 & 797.55 & 719.22 & 1.11 & 752.40 & 1.06 \\
\hline 6 & CFSTC-6 & 808.33 & 719.22 & 1.12 & 752.40 & 1.07 \\
\hline 7 & CFSTC-7 & 819.14 & 840.81 & 0.97 & 895.41 & 0.91 \\
\hline 8 & CFSTC-8 & 830.91 & 840.81 & 0.99 & 895.41 & 0.93 \\
\hline 9 & CFSTC-9 & 725.94 & 667.62 & 1.09 & 705.26 & 1.03 \\
\hline 10 & CFSTC-10 & 741.64 & 667.62 & 1.11 & 705.26 & 1.05 \\
\hline 11 & CFSTC-11 & 755.64 & 774.45 & 0.98 & 826.65 & 0.91 \\
\hline 12 & CFSTC-12 & 769.10 & 774.45 & 0.99 & 826.65 & 0.93 \\
\hline
\end{tabular}

$\mathrm{E}_{\mathrm{c}}=\mathrm{W}_{\mathrm{c}}^{1.5 \mathrm{ff}_{\mathrm{f}} 1}$

Table10. Comparison of experimental ultimate loads and design ultimate loads

4. CONCLUSIONS

- The axial load carrying capacity of CFST columns was increased by

$19.3 \%$ and $38 \%$ for $\mathrm{M}_{20}$ and $\mathrm{M}_{40}$.

$17.3 \%$ and $22.2 \%$ for $\mathrm{M}_{20}$ and $\mathrm{M}_{40}$.

$19.7 \%$ and $24.3 \%$ for $\mathrm{M}_{20}$ and $\mathrm{M}_{40}$.

- The average ultimate load carrying capacity of Concrete Filled Steel Tubular frames was increased by

$22.5 \%$ and $48.9 \%$ for $\mathrm{M}_{20}$ and $\mathrm{M}_{40}$. 
- The theoretical axial load carrying capacity of Concrete Filled Steel Tubular columns evaluated in accordance with AISC-LRFD 2005 and Eurocode 4 were found to be in best agreement.

- The maximum percentage variation for experimental results and theoretical results of axial load carrying capacity of CFST columns evaluated in accordance with

AISC-LRFD 2005 was around $21 \%$.

Eurocode 4 was around $16 \%$.

- Although there was some variation in the results between the experimental and theoretical results, but the experimental results were on the conservative side.

- The failure of the CFST columns of height $0.5 \mathrm{~m}$ was basically due to the local buckling near the mid height compare to the failure of Hollow Steel Tubular columns which failed due to inward local buckling near the ends.

- The failures of the CFST columns of height $1.0 \mathrm{~m}$ and $1.5 \mathrm{~m}$ were basically due to the overall buckling which was very much similar in case of Hollow Steel Tubular columns.

\section{REFERENCES}

N. Jamluddin, D. Lam, X.H. Dai and J.Ye (2013),”An experimental study on elliptical concrete filled columns under axial compression", Journal of constructional steel research, issue 87, pp 6-16.

Abdelmaseeh Bakos Keryou and Gailan Jibrael Ibrahim (2014), "Axial load carrying capacity of thin walled HSS stub columns filled with waste glass concrete", IJERSTE, vol 3, issue 5, pp 101-111.

Shedeh Ghannam, Hamid R. Al-Ani and Orabi-Al-Rawi, "Comparative study of load carrying capacity of steel tube filled light weight concrete and normal concrete", Jordan journal of civil engineering, vol 4, issue 2, 2010, pp 164-169.

J.Zeghiche and K.Chaoui, "An experimental behaviour of concrete filled steel tubular columns", Journal of constructional steel research, issue 61, 2005, pp 53-66.

Muhammad Naseem Baig, FAN Jiansheng and NIE Jianguo, "Strength of concrete filled steel tubular columns", Tsinghua science and technology, vol 11, issue 6, 2006, pp 657-666.

Lanhui Guo, Sumei Zhang, Wha-Jung Kim and Gianluca Ranzi, "Behaviour of hollow steel tubes and steel tubes filled with concrete", Science direct (www.elsevier.com), issue 45, 2007, pp 961973.

E K Mohanraj, S Kandasamy and A Rajaraman "Seismic behaviour of concrete filled steel tubular beams", $35^{\text {th }}$ conference on OUR WORLD IN CONCRETE AND STRUCTURES, 2010.

\section{AUTHOR's BIOGRAPHY}

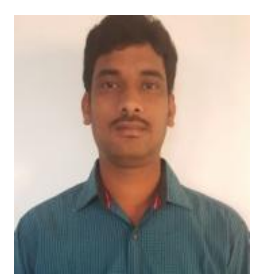

Pandu Ranga Kiran Kumar.T, got bachelor of technology in civil engineering from JNTU-KAKINADA University. I did the project on COMPARATIVE STUDY OF CONCRETE FILLED STEEL TUBE COLUMNS BY AXIAL COMPRESSION in M.Tech Structural engineering with my guide D.Aditya sai Kumar at Mandava institute of engineering and technology, jaggaipeta, Andhra Pradesh.

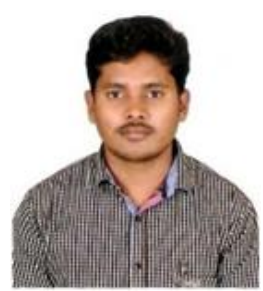

S.V.V.K.Babu, was born in Machilipatnam, India, in 1991. He received the B.Tech. degree in civil engineering from the University of JNTU KAKINADA, Andhra Pradesh in 2013, and the M.Tech. degree in structural engineering from the University of JNTU KAKINADA in 2015. In 2015, he joined as a Assistant Professor in the Department of Civil Engineering, College of Sri Vasavi Institute of Engineering \& Technology, Nandamuru, Andhra Pradesh. 